\title{
Anaerobic oxidation of petroleum hydrocarbons in enrichment cultures from sediments of the Gorevoy Utes natural oil seep under methanogenic and sulfate-reducing conditions
}

Olga N. Pavlova ( $\sim$ pavlova@lin.irk.ru )

Russian Academy of Sciences https://orcid.org/0000-0001-5074-222X

Oksana N. Izosimova

Russian Academy of Sciences

Svetlana M. Chernitsyna

Russian Academy of Sciences

Vyacheslav G. Ivanov

Russian Academy of Sciences

Tatyana V. Pogodaeva

Russian Academy of Sciences

Andrey V. Khabuev

Russian Academy of Sciences

Alexander G. Gorshkov

Russian Academy of Sciences

Tamara I. Zemskaya

Russian Academy of Sciences

\section{Research Article}

Keywords: Lake Baikal, anaerobic oxidation, petroleum hydrocarbons, microbial community

Posted Date: April 8th, 2021

DOl: https://doi.org/10.21203/rs.3.rs-400517/v1

License: @ (i) This work is licensed under a Creative Commons Attribution 4.0 International License.

Read Full License

Version of Record: A version of this preprint was published at Microbial Ecology on July 13th, 2021. See the published version at https://doi.org/10.1007/s00248-021-01802-y. 


\section{Abstract}

This article presents the first experimental data on the ability of microbial communities from sediments of the Gorevoy Utes natural oil seep to degrade petroleum hydrocarbons under anaerobic conditions. Like in marine ecosystems associated with oil discharge, available electron acceptors, in particular sulfate ions, affect the composition of the microbial community and the degree of hydrocarbon conversion. The cultivation of the surface sediments under sulfate-reducing conditions led to the formation of a more diverse bacterial community and greater loss of $n$-alkanes $(28 \%)$ in comparison to methanogenic conditions (6\%). Microbial communities of both surface and deep sediments are more oriented to degrade polycyclic aromatic hydrocarbons (PAHs), to which the degree of the PAH conversion testifies (up to $46 \%$ ) irrespective of the present electron acceptors. Uncultured microorganisms with the closest homologues from thermal habitats, sediments of mud volcanoes and environments contaminated with hydrocarbons mainly represented microbial communities of enrichment cultures. The members of the phyla Firmicutes, Chloroflexi, and Caldiserica (OP5), as well as the class Deltaproteobacteria and Methanomicrobia, were mostly found in enrichment cultures and belong to the "core" of microorganisms The influence of gas-saturated fluids may be responsible for the presence in the bacterial 16S rRNA gene libraries of the sequences of "rare taxa": Planctomycetes, Ca. Atribacteria (OP9), Ca. Armatimonadetes (OP10), Ca. Latescibacteria (WS3), Ca. division (AC1), Ca. division (OP11), and Ca. Parcubacteria (OD1), which can be involved in hydrocarbon oxidation.

\section{Introduction}

Deep petroleum reservoirs and deep sediments associated with oil discharge have long been considered biotopes unsuitable for life [1]. In recent decades, the use of a set of methods has described microbial diversity in petroleum reservoirs, revealed dominant groups of microorganisms that carry out anaerobic oxidation of oil, determined metabolic pathways and the resulting oxidation products [2-11]. Comparison of microbial diversity in petroleum reservoirs throughout the world indicated an obvious correlation of prokaryotic communities with temperature and depth of reservoir as well as no influence of the geographical distance between reservoirs. The members of Epsilonproteobacteria and Deltaproteobacteria were mostly detected in relatively shallow and low-temperature petroleum reservoirs, whereas Clostridiales and Thermotogales were more often found in deeper and higher-temperature petroleum reservoirs [11]. The study of the strategy of energy and carbon adsorption by microbial communities from three deep oil seepages (water column depth $3 \mathrm{~km}$ ) in the eastern part of the Gulf of Mexico using metagenomic, geochemical and metabolomic analyses revealed that deep sediments contain phylogenetically and functionally diverse microbial communities that carry out anaerobic metabolism of hydrocarbons where acetate and hydrogen are the central intermediates underpinning community interactions and biogeochemical cycling in these deep sediments. The microbial community was dominated by the members of the phylum Chloroflexi (mostly classes Dehalococcoidia and Anaerolineae), Ca. Atribacteria, Proteobacteria (mostly class Deltaproteobacteria), and Ca. Bathyarchaeota, whose genomes contain genes of anaerobic oxidation of hydrocarbons through 
hydroxylation and addition of hydrocarbons to fumarate as well as of degradation of anaerobic aromatic compounds through class I benzoyl-CoA reductase [12].

In the absence of oxygen, petroleum hydrocarbons can be biodegraded with , , and as alterative electron acceptors, which link to four typical reducing conditions [13]. In the past two decades, researchers have started to compare the performance of petroleum hydrocarbons degradation when different electron acceptors are employed, and it was indicated that the biodegradation behaviours of petroleum hydrocarbons may vary under various reducing conditions [14].

In contrast to marine ecosystems, natural oil seepages in freshwater lakes is rather a rare phenomenon known only for deep Lake Tanganyika (Central Africa), shallow Lake Chapala (Mexico) and deep oligotrophic Lake Baikal (Russia) [15-17]. The processes of anaerobic oxidation of oil in sediments of freshwater lakes have not been studied previously. Lake Baikal is one of the promising sites for studying ecology, taxonomic structure and geochemical activity of anaerobic microbial communities in sediments associated with the discharge of hydrocarbons. Among the unique characteristics of Lake Baikal, there are not only its age (more the 25 million years), depths and dimensions close to marine ones but also the presence of natural oil seepages. Oil in Lake Baikal, which was formed during the Oligocene and the Early Miocene, is the permanent component of the ecosystem characterized by a young age, specificity of the original organic matter and the presence of a complex of unique biomarker molecules in its composition $[17,18]$.

There are two known sites of oil seepage in Lake Baikal: one is located at the estuary of the Bolshaya Zelenovskaya River, which was was discovered at the end of the $18^{\text {th }}$ century; the second - near Gorevoy Utes Cape (discovered in 2005) (Fig. 1a). The site of Gorevoy Utes Cape is an oil and methane seep with seepages of gas, oil and deep waters migrating through reservoirs of the lower seismic complex (from a depth of $\sim 4 \mathrm{~km}$ ) to the permeable fault zone where via vertical migration they come to the bottom surface [18]. Oil is discharged through asphalt structures. In places where oil accumulated on a flat area and near the structures, hydrocarbon gases discharged, which contained $99 \%$ of methane and approximately $1 \%$ of its homologues [19]. There were dense populations of benthic animals on asphalt structures, whose density was an order of magnitude higher than that at the reference sites of the bottom [20] (Fig. 1b).

The discovery of the new site of oil seepage in 2005 provided online monitoring of qualitative and quantitative changes in the oil composition as well as study of the diversity of the microbial community and its role in the processes of oil degradation. In 2005, the oil collected at the moment of its emergence on the water surface showed an extremely high $n$-alkane concentration and was identified as nonbiodegraded paraffinic oil $[17,18]$. At present, the oil composition shows a narrowing of the homologous series of $n$-alkanes, a decrease in the total concentration of normal hydrocarbons and polycyclic aromatic hydrocarbons (PAHs) as well as partial degradation of oil coming to the water surface [21]. Previous studies have revealed that aerobic hydrocarbon-oxidizing microorganisms contribute significantly to the self-cleaning of the lake from oil "pollution" [22]. 
At the same time, studies of microorganisms involved in oil degradation in the anaerobic zone of the sedimentary strata of Lake Baikal are at an early stage [23]. The question of the possible electron acceptors, the composition of microbial community and the role of anaerobic prokaryotes in these processes remains open. In this regard, we carried out the model experiments with the sediments from the Gorevoy Utes natural oil seep. They aimed to determine phylogenetic diversity of oil-degrading microorganisms in the cultures enriched with bicarbonate/sulfate ion in comparison with the conversion degree of $n$-alkanes and PAHs (two important petroleum hydrocarbon components) under methanogenic and sulfate-reducing conditions.

\section{Material And Methods}

\section{Sampling}

Two integrated samples of sediments were collected with a gravity corer in the zone of hydrocarbon discharge near Gorevoy Utes Cape (10 km off the coast, water column depth 890 m, Central Baikal; coordinates $53^{\circ} 30^{\prime} 45^{\prime \prime} \mathrm{N}, 108^{\circ} 39^{\prime} 12^{\prime \prime} \mathrm{E}$ ) in 2018 . The first core sample, St.5 GC. 3 (GUI), corresponded to a core depth of 10 to $30 \mathrm{~cm}$; the second (GUII) -100 to $120 \mathrm{~cm}$ (Fig. 1c). The GUI sample contained oil; the GUII contained not only oil but also gas hydrates.

\section{Enrichment culture}

To obtain enrichment cultures, samples of sediments were aseptically taken from the central part of the core and immediately placed into $116 \mathrm{~mL}$ vials containing $50 \mathrm{~mL}$ of sterile anaerobic modified Pfennig's mineral solution [24] with reduced salt content, taking into account low- mineralized conditions of Lake Baikal $\left(0.25 \mathrm{~g} / \mathrm{L} \mathrm{NaCl}, 0.1 \mathrm{~g} / \mathrm{L} \mathrm{KCl}, 0.1 \mathrm{~g} / \mathrm{L} \mathrm{NH}_{4} \mathrm{Cl}, 0.1 \mathrm{~g} / \mathrm{L} \mathrm{KH}_{2} \mathrm{PO}_{4}, 0.2 \mathrm{~g} / \mathrm{L} \mathrm{MgCl}{ }_{2} \cdot 6 \mathrm{H}_{2} \mathrm{O}, 0.1 \mathrm{~g} / \mathrm{L}\right.$ $\mathrm{CaCl}_{2} \cdot 2 \mathrm{H}_{2} \mathrm{O}, 1 \mathrm{~g} / \mathrm{L} \mathrm{NaHCO}_{3}, 1 \mathrm{~mL}$ vitamin solution, $1 \mathrm{~mL}$ trace element solution according to [25]). The vials were closed with rubber stoppers and aluminium caps, purged with oxygen-free nitrogen and shaken for 15 minutes at 160-180 rpm in orbital shaking (OS-20, BioSan, Riga, Latvia). The resulting suspension was transferred with a syringe into vials with a mineral solution $(70 \mathrm{~mL})$ of the above composition containing a gaseous mixture of $\mathrm{N}_{2} / \mathrm{CO}_{2}(90: 10 \mathrm{v} / \mathrm{v})$. Sulfate-reducing conditions were established in microcosms by the addition of $\mathrm{Na}_{2} \mathrm{SO}_{4}$ (final concentration $20 \mathrm{mM}$ ) to the solution, and $\mathrm{Na}_{2} \mathrm{~S}(0.5 \mathrm{mM})$ was added as a reducing agent. Methanogenic microcosms were prepared as sulfate-reducing microcosms but without adding $\mathrm{Na}_{2} \mathrm{SO}_{4}$. Therefore, four enrichment cultures were obtained for the analysis: $\mathrm{GUI}_{2} \mathrm{HCO}_{3}, \mathrm{GUI}_{-} \mathrm{SO}_{4}, \mathrm{GUII}_{-} \mathrm{HCO}_{3}$, and $\mathrm{GUII}_{-} \mathrm{SO}_{4}$.

Approximately $50 \mu \mathrm{l}$ of non-biodegraded crude oil (Angarsk Petrochemical Company, Russia) was added as a carbon and energy source to triplicate enrichment culture. A sterile medium with oil without adding sediment samples was used as a negative control. All enrichment cultures were incubated $10{ }^{\circ} \mathrm{C}$ in the dark without mixing. 
Gaseous hydrocarbons in the experimental vials and sediments were determined by a modified phaseequilibrium degassing method where the error in determining the methane concentration was $\pm 5 \%[26]$.

\section{Determination of polycyclic aromatic hydrocarbons and $n$-alkanes in model experiments}

The samples taken in the course of model experiments were heterogeneous mixtures, including a mineral aqueous solution, sediments with a microbial community formed under conditions of oil seepage and crude oil additives. Before analysis, the samples were centrifuged; the aqueous fraction was separated from the sediment of the heterogeneous mixture. Before the determination of $n$-alkanes and PAHs, 20 $100 \mu \mathrm{L}$ of squalane (in dichloromethane, $0.60-30 \mu \mathrm{g} / \mu \mathrm{L}$ ), $30-200 \mu \mathrm{L}$ of a mixture of deuterated polycyclic aromatic hydrocarbons: naphthalene- $d_{8}$; acenaphthene- $d_{10}$, phenanthrene- $d_{10}$, chrysene- $d_{12}$, and perylene- $d_{12}$ (in a mixture of n-hexane: acetone $(1: 1) ; 5-600 \mathrm{ng} / \mu \mathrm{L}$; Supelco, USA), were added to the aqueous fraction and the sediment of the heterogeneous mixture of samples as internal standards. The volume of the added standards was determined by the expected content of hydrocarbons in the sample.

During the determination of $n$-alkanes in the aqueous phase, hydrocarbons were twice extracted with dichloromethane; the extracts were combined, and the total extract $(9 \mathrm{~mL})$ was centrifuged for 3 minutes at $2000 \mathrm{rpm}$. Then, anhydrous $\mathrm{Na}_{2} \mathrm{SO}_{4}$ was added to $\sim 1 \mathrm{~mL}$ aliquots of the extract, the mixture was shaken and centrifuged, and the supernatant was transferred to the autosampler vial of the chromatograph. Hydrocarbons were extracted from the sediment of the heterogeneous mixture by ultrasonic $(35 \mathrm{kHz})$ extraction with $5 \mathrm{~mL}$ of dichloromethane for 15 minutes. The extract was separated by centrifugation at $3000 \mathrm{rpm}$; anhydrous $\mathrm{Na}_{2} \mathrm{SO}_{4}$ was added to $\sim 1 \mathrm{~mL}$ aliquots of the extract; the mixture was shaken and centrifuged, and the supernatant was transferred to the autosampler vial of the chromatograph.

To determine PAHs, $1 \mathrm{ml}$ of $\mathrm{n}$-hexane was added to aliquots of the obtained extracts, $\sim 0.1 \mathrm{ml}$; the mixture was shaken, left for $\sim 24$ hours at a temperature of $+4{ }^{\circ} \mathrm{C}$ and then centrifuged. The upper layer of $\mathrm{n}$ hexane was separated; anhydrous $\mathrm{Na}_{2} \mathrm{SO}_{4}$ was added; the mixture was shaken and centrifuged; the supernatant was transferred into the autosampler vial of the chromatograph.

The prepared samples were analyzed by gas chromatography-mass spectrometry (GC-MS, Agilent, GC 6890, MSD 5973, USA) under the following conditions: OPTIMA® 17 MS Macherey-Nagel column (30 m × $0.25 \mathrm{~mm} 0.25 \times \mu \mathrm{m})$ and $\mathrm{He}$ as a carrier gas. The GC operating parameters were as follows: from $50{ }^{\circ} \mathrm{C}$ ( $0.5 \mathrm{~min}$ initial time) to $300^{\circ} \mathrm{C}$ at $10^{\circ} \mathrm{min}^{-1}$ (isothermal for $25 \mathrm{~min}$ final time) for $n$-alkanes and from 95 ${ }^{\circ} \mathrm{C}\left(0.5 \mathrm{~min}\right.$ initial time) to $310^{\circ} \mathrm{C}$ at $10^{\circ} \mathrm{min}^{-1}$ (isothermal for $5 \mathrm{~min}$ final time) for PAHs. The temperature of the injector was $290^{\circ} \mathrm{C}$; the temperature of the dispenser was $250^{\circ} \mathrm{C}$; the volume of the injected sample was $2 \mu \mathrm{L}$ without flow splitting, and the electron impact ionization was $70 \mathrm{eV}$. For $n$-alkane quantification, the peaks were registered by ion monitoring with 57 and $71 \mathrm{~m} / \mathrm{z}$, for PAHs quantification, the peaks were registered by ion monitoring with $128,142,152,154,166,178,192,202,228,252,276$, and $278 \mathrm{~m} / z$. The quantification of $n$-alkanes and PAHs in the supernatant and the sediment was carried out according to the method of an internal standard. The results were summarized and presented as the 
concentration of $n$-alkanes and PAHs in the samples collected during the model experiment. Recovery averages were $85 \%$ for $n$-alkanes and PAHs. The precision measurements of absolute concentrations of $n$-alkanes and PAHs were less than $15 \%$.

The chemical composition of pore waters from the sediments was determined as described previously [27].

\section{Molecular identification methods}

DNA was extracted from enrichment cultures according to the modified method of enzymatic lysis technique followed by phenol-chloroform extraction [28]. The fragments of the 16S rRNA gene were amplified using universal bacterial (27F and1350R) [29] and archaeal primers (21F and 958R) [30]. PCR was carried out using kits (Intifinica, Russia) according to the manufacturer's instructions. The obtained fragments of the 16S rRNA gene were cloned and transformed using the pGEM-T Easy Vector Systems reagent kit (Promega, USA) according to the manufacturer's protocol. For the analysis, 30 clones containing inserts were selected from each library. The Sanger sequencing was performed using the BigDye Terminator Kit v.3.1 reagents on an ABI 3130XL Genetic Analyser (Applied Biosystems, USA). The primary analysis of the similarity in the nucleotide sequences of the 16S rRNA genes obtained from the enrichment cultures with known sequences from GenBank was carried out using the BLAST software package (www.ncbi.nlm.nih.gov/blast). The presence of chimeras was determined through analysis of sequences using the PINTAIL programme (http://www.cardiff.ac.uk/biosi/research/biosoft). The phylogenetic tree was constructed by neighbour-joining using the cluster method and Kimura's twoparameter model implemented in the MEGA X software [31].

\section{Results And Discussion}

\section{Lithological characteristics of sediments}

In the upper interval (from the surface to $50 \mathrm{~cm}$ ) of the St. $5 \mathrm{GC}$. 3 core, sediments are represented by reduced diatomaceous aleurite-pelitic ooze with oil inclusions; in the middle interval (from 50 to $65 \mathrm{~cm}$ ) by a watered and oil-saturated aleurite layer; in the lower one (from 120 to $151 \mathrm{~cm}$ ) - grey clay with many oil inclusions and massive stratified gas hydrates. The sediments of the St.5, GC.3 core were highly saturated with gas; the methane concentration varied from 4 to $18 \mathrm{mM} / \mathrm{L}$ along the core depth (Fig. 2a). The highest methane concentrations were recorded at depths of 20 and $100 \mathrm{~cm}(13$ and $18 \mathrm{mM} / \mathrm{L}$, respectively). Methane homologues in the gas were mainly represented by ethane (from 1 to $10 \mu \mathrm{M} / \mathrm{L}$ ).

Pore waters of sediments in all sedimentary layers were of bicarbonate-calcium-sodium type. Salinity was higher than background one [32]; total ions varied from $136.6 \mathrm{mg} / \mathrm{L}$ to $278.8 \mathrm{mg} / \mathrm{L}$ along the depth of the core. Pore waters were enriched with bicarbonate ions (up to $3.3 \mathrm{mM} / \mathrm{L}$ at a depth of $80 \mathrm{~cm}$ ) $($ Fig. $2 b)$. Nitrate $(0.7-1.4 \mu \mathrm{M} / \mathrm{L})$, and nitrite ions $(0.7-4.5 \mu \mathrm{M} / \mathrm{L})$ were present along the entire profile of the core. The concentration of sulfate ions was lower along the entire core depth than at the reference sites and in the Baikal water [27, 32], accounting for 2.9 to $8.3 \mu \mathrm{M} / \mathrm{L}$ (Fig. 2C). 


\section{Degradation of hydrocarbons under methanogenic and sulfate-reducing conditions}

Cultivation of microbial communities in the cultures enriched with bicarbonate ions and sulfate ions for one year revealed a different degree of conversion for $n$-alkanes and PAHs. In the GUI sample, the greatest loss of $n$-alkanes (28\%) was determined during the cultivation of the microbial community under sulfatereducing conditions where the $\Sigma_{\text {alk }}$ content in the sample decreased to $5000 \mu \mathrm{g}$ in comparison with control enrichment cultures $(7000 \mu \mathrm{g})$. Under metagenomic conditions, a decrease in the number of

alkane fraction of oil was insignificant $(6600 \mu \mathrm{g})$, accounting for $6 \%$. The $\Sigma_{\text {PAH }}$ concentration in the presence of sulfate and bicarbonate ions in the $\mathrm{GUI}_{-} \mathrm{SO}_{4}$ and $\mathrm{GUI}_{-} \mathrm{HCO}_{3}$ enrichment cultures decreased by 20 to $37 \%$, respectively (Fig. 3). Conversion of oil hydrocarbons in $\mathrm{GUI}_{-} \mathrm{HCO}_{3}$ was accompanied by the generation of methane. A native sample of sediments was initially saturated with gas; the methane concentration in the enrichment cultures at the beginning of the experiment was $13 \mathrm{mM} / \mathrm{L}$. After three months of cultivation, the methane concentration increased to $27 \mathrm{mM} / \mathrm{L}$. Its highest concentration (32 $\mathrm{mM} / \mathrm{L}$ ) was recorded after six months of cultivation in the enrichment cultures containing the surface sample of sediments. This level of methane concentration was maintained until the end of the experiment (31 mM/L).

In the cultures with deep sediments (GUII) enriched with bicarbonate ion, the conversion of $n$-alkanes was $20 \%$, and in those enriched with sulfate ion - less than $1.5 \%$ (Fig. 3). The degree of PAH conversion was $45-46 \%$ irrespective of the present electron acceptors. In the GUll enrichment cultures, the methane concentrations during the entire experiment remained almost the same (3.0 to $3.8 \mathrm{mM} / \mathrm{L}$ ) because the values were comparable to those determined at the beginning of the experiment ( $3.2 \mathrm{mM} / \mathrm{L})$. The loss of sulfate ions in the enrichment cultures containing both surface and deep samples was $25 \%$ of the initial concentration.

\section{Bacterial and archaeal community composition in enrichment culture under methanogenic conditions}

Analysis of the $16 \mathrm{~S}$ rRNA gene clone libraries of bacterial communities revealed the members of 12 phyla in the $\mathrm{GUI} \_\mathrm{HCO}_{3}$ and $\mathrm{GUII} \_\mathrm{HCO}_{3}$ enrichment cultures. Bacteria assigned to Firmicutes, Chloroflexi, Proteobacteria ( $\delta$ ), and Armatimonadetes (OP10) were common to two samples. The members of the phylum Bacteroidetes and Ca. Aminicenantes (OP8) were found only in the enrichment culture of the surface sample; Proteobacteria (a), Caldiserica (OP5), Ca. Atribacteria (OP9), Ca. division (AC1), Ca. division (OP11), and Ca. Parcubacteria (OD1) - only in the enrichment culture of the deep sample (Fig. 4).

In the $\mathrm{GUI} \_\mathrm{HCO}_{3}$ clone library, the bulk of the Firmicutes sequences (20 clones) belonged to uncultured bacteria from the sediments of freshwater lakes, Antarctic cold seeps and oil sands tailings (Supplementary Table S1). In the $16 \mathrm{~S}$ rRNA gene library of the $\mathrm{GUII}_{2} \mathrm{HCO}_{3}$ sample, five sequences showed the highest similarity to the members of Peptococcaceae (Fig. 5). 
The members of the phylum Chloroflexi were the second most common bacteria in gene libraries. Their largest number (10 clones) was identified in the GUII_HCO 3 library. In the phylogenetic tree, they did not form a single cluster but separate branches with the sequences of uncultured bacteria retrieved in the sediments of the cold methane seep in the Sea of Okhotsk, mud volcanic sediments and oil sands tailings during anaerobic biodegradation of longer-chain $n$-alkanes (Fig. 5). The sequences from the surface sample (three clones) were homologous to the sequences of uncultured bacteria from riverine sediments contaminated with nitrobenzene as well as to consortium of microorganisms involved in anaerobic digestion of sludge.

The members of the phylum Proteobacteria ( $\delta$ ) and Armatimonadetes (OP10) were minor (one clone in each library). The uncultured Syntrophaceae bacteria and bacterial sequences of the genera Syntrophus sp. and Smithella sp., whose cultured homologues were obtained from syntrophic associations of methanogenic archaea and propionate-, benzoate- and alkane-oxidizing microorganisms, represented the phylum Proteobacteria ( $\delta$ ).

The bacterial sequences assigned to the phylum Bacteroidetes (two clones), which were detected only in the surface sample, were homologous to the uncultured bacteria from chemolithotrophic denitrification reactor and sediments of low-sulfate Lake Pavin. Three clones were assigned to Candidate division OP8. These clones were closely related to uncultured bacteria from water-flooded petroleum reservoirs, wastewater and freshwater ecosystems.

The 16S rRNA gene library of bacteria from the deep sample was very diverse. There were six sequences assigned to the uncultured candidate division AC1 bacterium, poorly known taxa detected in the deeper layers of lakes [33], forming two subclusters in the phylogenetic tree. One sequence cluster was homologous to the uncultured bacteria from the PAH degrading bacterial community of contaminated soil; another - to the sequences of the uncultured bacteria from the sediments of Lake Biwa and phreatic limestone sinkholes, Mexico. The phylum Caldiserica was the next most represented in the gene library (three clones). The sequences were 96 to $99 \%$ homologous to the sequences of the uncultured bacteria from boreal oligotrophic peat wetlands and subalpine stream sediments and $94 \%$ - to the uncultured bacteria from thermal vents in Yellowstone Lake (Supplementary Table 1S).

Minor sequences (one clone each) were identified as the members of the phyla Proteobacteria (a) and Ca. Atribacteria (OP9). The Caldovatus sediminis and Crenalkalicoccus roseus thermophils isolated from hot springs were the closest homologues of the MW595807 (Proteobacteria a) sequence. The MW595808 clone was identified as uncultured bacteria closely related to microorganisms from the candidate phylum Atribacteria (OP9) found in the methanogenic reactor and boreal oligotrophic peat wetlands (Fig. 5). Two sequences from the gene library of the deep sample had low similarity (82 to 93\%) with uncultured bacteria from the candidate phylum, OD1 (also referred to as Parcubacteria), and Ca. division (OP11) (not shown in the phylogenetic tree). 
The members of the phylum Euryarchaeota and TACK group archaeon were detected in the 16S rRNA clone library of archaeal genes from the $\mathrm{GUI} \mathrm{HCO}_{3}$ enrichment culture. The phylum Euryarchaeota (20 clones) was represented by the orders Thermoplasmata and Methanomicrobia, whose closest homologues had been identified in Canadian oil sands reservoir, gas-hydrate potential area, freshwater, and sea floor sediments (Supplementary Table 2S) (Fig. 6). TACK group archaeon consisted of 10 sequences, the closest homologues of which were detected in groundwater of the deep-well injection site, Tomsk-7 (Russia) and in sediments with different geographical locations. The MW617261 clone was related (98\%) to uncultured "Aigarchaeota" archaeon from the microbial community of thermal vents in Yellowstone Lake. Currently "Aigarchaeota" is a proposed archaeal phylum combining features of hyperthermophilic and mesophilic life during the evolution of its lineage [34].

Notably, the sequences from the 16S rRNA gene library of bacteria from the microbial community of thermal vents in Yellowstone Lake already appeared in this study during the analysis of the gene library of bacteria from the GUII_HCO ${ }_{3}$ enrichment culture. Thus, the MW595804 clone showed a similarity of 94\% to uncultured Candidate Division OP5 from Yellowstone Lake.

The $16 \mathrm{~S}$ rRNA library of archaeal genes of the GUII_HCO $\mathrm{HCO}_{3}$ enrichment culture was less diverse in the composition than the GUI_HCO ${ }_{3}$ enrichment culture. The gene library was $100 \%$ composed of the sequences, the closest homologues of which were identified in peatland ecosystems (Supplementary Table 2S). Of them, $87 \%$ were the sequences of the uncultured Methanomicrobiales archaeon, and $13 \%-$ the sequences of uncultured bacteria that formed a branch in TACK group archaeon (Fig. 6).

\section{Bacterial and archaeal community composition in enrichment culture under sulfate-reducing conditions}

In the gene libraries of both samples, more than $30 \%$ of the detected sequences belonged to microorganisms of the phylum Caldiserica, an anaerobic, thermophilic and thiosulfate-reducing bacterium [35] (Fig. 4). Sequences of the uncultured bacteria detected in the hydrocarbon-contaminated aquifer and pristine subalpine stream sediments were the closest homologues (Fig. 4). The members of the phylum Firmicutes, the families Thermoactinomycetaceae and Gracilibacteraceae, as well as unclassified Clostridia, were the second most common microorganisms. The members of the phyla Proteobacteria (ठ), Ca. Atribacteria (OP9) and Chloroflexi were common for both samples.

The sequences assigned to the phylum Proteobacteria $(\delta)$ had high similarity with uncultured deltaproteobacteria from Zacaton (volcanically controlled hypogenic karst, Tamaulipas, Mexico) and with Syntrophus sp. previously detected in the enrichment cultures of this study under methanogenic conditions. The phylum Chloroflexi was also represented by the sequences that were previously detected in the enrichment cultures enriched with bicarbonate ion.

Sequences of the phyla Ca. Latescibacteria, Bacteroidetes, Actinobacteria, and Planctomycetes were detected only in the surface sample, and the phyla Acidobacteria and Ca. division (AC1) - only in the deep sample (Fig. 7). The sequences assigned to the phylum Planctomycetes had a low similarity (90 to 92\%) with the closest homologues from methane hydrate-bearing deep marine sediments in the Pacific 
Ocean and deep-sea mud volcanoes in Eastern Mediterranean. One of the sequences was assigned to Ca. division WS3 (Latescibacteria). Metabolic reconstruction suggests a prevalent saprophytic lifestyle in all "Latescibacteria" orders, with marked capacities for the degradation of proteins, lipids and polysaccharides predominant in the plant, bacterial, fungal/crustacean, and eukaryotic algal cell walls [36]. Uncultured eubacterium clone from industrial and mining acid sulfate wastewaters was the only closest homologue (98\%) of this sequence.

Two clones related to uncultured Actinobacteria from boreal oligotrophic peat wetlands and an ammonium-rich aquifer-aquitard system in the Pearl River Delta (China) had a low similarity (Supplementary Table 3S). In the phylogenetic tree, two clones from the gene library of the deep sample (MW617252) formed a branch in a separate cluster and were similar to uncultured candidate division AC1 bacterium from deepest phreatic sinkhole and sediment of a freshwater Lake Biwa. Two other sequences with unclear phylogenetic position formed another branch in this cluster (Fig. 7).

The clone library of the 16S rRNA archaeal genes from the GUI_SO 4 enrichment culture consisted of $100 \%$ members of Euryarchaeota. In the phylogenetic tree, sequences of the order Methanomicrobia formed three branches (Fig. 8). The group with the greatest number of sequences (22 clones) clustered with uncultured euryarchaeota from sinkhole ecosystems, which had been previously identified in the archaeal gene library of the cultures enriched with bicarbonate ions and of Methanoregula formicica, methaneproducing archaeon isolated from methanogenic sludge. Five sequences showed the highest similarity with the members of Methanosaeta sp. from the microbial community of anaerobic methanotrophic archaea of the ANME-2d cluster in freshwater sediments of Lake Ørn. The sequences homologous to the archaeal sequences from the microbial community of freshwater sediments of Lake Ørn was already identified in the gene library of archaea from the surface sample, which had been cultivated under methanogenic conditions (Supplementary Table 4S). Three clones were related (98\%) to uncultured euryarchaeote from the microbial community of thermal vents in Yellowstone Lake (Supplementary Table 4S).

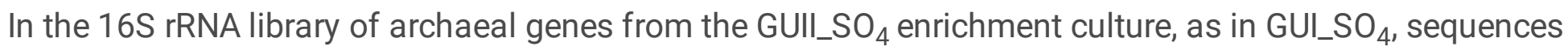
of the order Methanomicrobia from sinkhole ecosystems dominated (87\%). Five sequences showed the highest similarity to uncultured Methanomicrobiales archaeon from the Canadian oil sands reservoir. TACK group archaeon was represented by two sequences with 97-96\% identity with the sequences of uncultured archaea from sediments of various ecosystems (Supplementary Table 4S).

\section{Discussion}

In subsurface and deep sediments of the Gorevoy Utes natural oil seep, under methanogenic and sulfatereducing conditions, we recorded the loss of $n$-alkanes and PAHs accompanied by the methane formation. In the enrichment cultures containing surface sediments, the $n$-alkane conversion was the most intense in the presence of sulfate ions, and in those containing deep ones - of bicarbonate ions, which can be due to the composition of microbial communities developing under various conditions. In 
deep sediments, the microbial community is more oriented to the anaerobic oxidation of PAHs, to which a high degree of their biodegradation (up to $46 \%$ ) testifies, regardless of the present electron acceptors.

Cultivation of the surface sediment under methanogenic conditions led to the dominance of the members of the phylum Firmicutes in enrichment cultures, whose closest homologues are uncultured bacteria from sediments of freshwater bodies with unknown metabolism that is likely not associated with anaerobic oxidation of hydrocarbons. The members of the phylum Chloroflexi and $\mathrm{Ca}$. Aminicinantes (OP8) can provide the loss of $n$-alkanes in the $\mathrm{GUI}_{-} \mathrm{HCO}_{3}$ enrichment culture. The members of the phylum Chloroflexi are regarded as microorganisms with a high level of hydrolytic enzymes indicating their involvement in the decomposition of complex organic matters [37]. The reconstructed central metabolic pathways suggested that Aminicenantes bacterium is an anaerobic organotroph capable of fermenting carbohydrates and proteinaceous substrates and of performing anaerobic respiration with nitrite [38]. At the same time, the members of the phylum Chloroflexi and Ca. Aminicinantes (OP8) are increasingly found in ecosystems associated with hydrocarbons. Ca. Aminicenantes are often found associated with fossil fuels and hydrocarbon-impacted environments; Chloroflexi harbouring genes for anaerobic hydrocarbon degradation have been found in hydrothermal vent sediments $[12,39,40]$. Perhaps, archaea assigned to the TACK group and the order Thermoplasmata, comprising 33 and $43 \%$, respectively, of the archaeal gene library of the GUI_HCO ${ }_{3}$ sample, participate in anaerobic alkane oxidation. Phylogenetic reconstructions, protein homologue modelling and functional profiling of metagenomes and genomes revealed that among Archaea, in addition to Archaeoglobi previously shown to have this capability, genomes of $\mathrm{Ca}$. Bathyarchaeota, Heimdallarchaeota, Lokiarchaeota, Thorarchaeota, and Thermoplasmata also suggest fermentative hydrocarbon degradation using archaea-type FAE [12, 41]. The ability to degrade oil in oil-contaminated soils was shown for methanogenic archaea of the families Methanomicrobiaceae, Methanosarcinaceae, and Ca. Methanofastidiosa as well as for the order Thermoplasmatales [42].

In the cultures enriched with bicarbonate ions, methane generation accompanied degradation of hydrocarbons. Methane generation rates in Lake Baikal vary significantly depending on the geological structure of the lake sites $[43,44]$. The methane concentration $(32.54 \mathrm{mM} / \mathrm{L})$ identified during the cultivation of the surface sample after six months of the experiment significantly exceeded the values that had been previously determined (up to $11.2 \mathrm{mM} / \mathrm{L}$ ) under conditions of laboratory modelling during the cultivation of microbial communities from the methane seep and mud volcanoes $[45,46]$.

In the deep sample, under methanogenic conditions, bacteria from the phylum Chloroflexi (proportion in the gene library - 33\%) and Firmicutes (17\%) represented by the order Peptococcaceae can play the main role in the alkane degradation. Microorganisms from the order Peptococcaceae are most often detected in anoxic environments associated with the anaerobic degradation of aromatic hydrocarbons [47] and in methanogenic short-chain alkane-degrading culture together with methanogenic Archaea (Methanosaetaceae and Methanomicrobiaceae) [48]. In the GUII_HCO ${ }_{3}$ enrichment cultures, the bulk of the archaeal sequences (83\%) was the members of the class Methanomicrobia. Despite the presence of sequences of syntrophic bacteria and methanogenic archaea in the gene libraries of the deep sample, 
there was no significant methane generation. In some cases, the absence of methane generation in deep sedimentary strata was previously shown both in native natural sediments and in the experimental conditions $[44,46]$, despite the presence of methanogenic archaea in the composition of microbial communities.

In marine sediments, sulfate ion is the most preferable electron acceptor, and the degradation rate of petroleum hydrocarbons gradually decreases under sulfate-reducing-methanogenic-nitrate-reducing conditions [49]. The content of sulfate ions in the fresh waters of Lake Baikal is not high $(55 \mu \mathrm{M} / \mathrm{L})$ [50]. In Baikal areas associated with hydrocarbon seepages, the concentrations of some ions in pore waters from sediments were abnormally high [27, 32]. No elevated concentrations of sulfate and nitrate ions were in the investigated core. The increased salinity was mainly due to the concentration of bicarbonate ions that do not prevent the development of microorganisms with different types of metabolism. The addition of sulfate ions into the experimental vials containing surface sedimentary layer led to the formation of a more diverse bacterial community and greater loss of $n$-alkanes in comparison with methanogenic conditions. The members of the phyla Caldiserica, Firmicutes and Chloroflexi, as well as of the class Deltaproteobacteria, occupied the dominant position there. Notably, in the 16S rRNA gene libraries of bacteria from GUI_HCO ${ }_{3}$ and $\mathrm{GUI}_{-} \mathrm{SO}_{4}$, we identified the same closest homologues assigned to Deltaproteobacteria, Chloroflexi and Methanomicrobia, despite the difference in cultivation conditions. The ability to adapt to sulfate stress was shown for bacteria of the genus Smithella and archaea of the genus Methanoculleus, the key alkane degraders and methane producers. In conditions of mixed electron acceptors, in the medium, depending on the sulfate concentration, there is a competition and coexistence of sulfate-reducing and methanogenic populations during the anaerobic decomposition of hexadecane [51], which, probably, also takes place in the Baikal sediments where the same microorganisms participate in the hydrocarbon degradation irrespective of the present electron acceptors.

Microorganisms present in enrichment cultures can be involved not only in the degradation of $n$-alkanes but also PAHs. Dong X. et al. [12] revealed that aromatic compounds can be anaerobically degraded by bacteria related to Dehalococcoidia, Anaerolineae, Deltaproteobacteria, Aminicenantes, and TA06, as well as by archaea (Thermoplasmata and $\mathrm{Ca}$. Bathyarchaeota), via channelling into the central benzoyl-CoA degradation pathway.

A decrease in the PAH concentration in the sediments of the oil seepage site near Gorevoy Utes Cape has been observed over the past ten years since the discovery of natural oil seepage in 2005. Thus, in 2006, $\Sigma_{\text {PAH }}(24$ compounds) in the sediments varied from 0.9 to $70 \mathrm{ng} / \mathrm{g}$, and in 2016 - from 1.6 to $16 \mathrm{ng} / \mathrm{g}$ [21, 52]. In contrast to PAHs in oil sampled from the lake and the water surface, the proportion of PAHs in oil from the sediments was relatively low [21]. The low PAH concentration is likely due to the impact of the microbial communities in both surface and deep sediments under anaerobic conditions regardless of the present electron acceptors where PAHs primarily undergo oxidation, and $n$-alkanes are mainly oxidized in the water column under aerobic conditions and sub-surface sediments in case of their enrichment with sulfates. This experiment indicates that the presence of sulfate ion affects the $n$-alkane degradation that occurs only in enrichment cultures containing surface sediments and less significant for the processes 
occurring in enrichment cultures containing deep sediments, which corresponds to the results of determining the activity of the sulfate reduction in the sediments of Lake Baikal. The activity of sulfate reduction (from 0.3 to $1200 \mathrm{nM} /\left(\mathrm{dm}^{3}\right.$ day)) is reliably recorded in the upper 15 to $20 \mathrm{~cm}$ [44] of sediments and up to $60 \mathrm{~cm}$ near the Posolsk Bank methane seep [53]. In deep sediments, the maximum rates of sulfate reduction did not exceed $7 \mathrm{nM} /\left(\mathrm{dm}^{3}\right.$ day) [44].

Therefore, the conducted experiments have revealed a wide range of microorganisms that are potential participants in oil biodegradation under anaerobic conditions of Lake Baikal. The detailed analysis of phylogenetic diversity in petroleum reservoirs on the global scale determined the core of the microbiome that includes three classes of bacteria ( $y$-Proteobacteria, Clostridia and Bacteroidia) and one class of archaea (Methanomicrobia), which are widespread in petroleum reservoirs and underlie the functioning of the ecosystem in petroleum reservoirs [11]. Grey and co-authors [54] presented similar results that the members of four phyla (Firmicutes, Proteobacteria, Bacteroidetes, and Methanomicrobia) are mostly found in petroleum reservoirs and environments contaminated with hydrocarbons (aquifers, sediments and soils). The results of comparing the structure of microbial communities from sediments associated with oil and from petroleum reservoirs confirm the general idea that the identified main composition of microbial communities participates in complex syntrophic interactions responsible for the complete degradation of alkanes and other hydrocarbon components [55]. Syntrophy is a key mechanism of anaerobic biodegradation of hydrocarbons not only under methanogenic conditions but also in the presence of sulfate ion, ferric iron or nitrate ion [56]. We also do not exclude syntrophic interactions for microbial communities in the Baikal sediments because, in all investigated samples, there were microbial communities that carry out interdependent sequential reactions in the general metabolic process that one member of the community cannot carry out [8].

The phylogenetic diversity revealed in methanogenic and sulfate-reducing microcosms that were obtained in this experiment mostly coincides with the composition of microorganisms included in the "microbiome core" of petroleum reservoirs. The members of the phyla Firmicutes, Chloroflexi, Caldiserica (OP5), as well as of the class Deltaproteobacteria, predominated in the bacterial 16S rRNA gene libraries. Archaea in the clone libraries of the 16S rRNA genes were mainly represented by the sequences of the class Methanomicrobia. In the experiment, there were no members of the class $\gamma$-Proteobacteria; the class Bacteroidia was present only in the surface sediments. At the same time, $\mathrm{Y}$-Proteobacteria and Betaproteobacteria ranged from 0.3 to 9 and 0.5 to $15 \%$, respectively, in the surface sediments of the oil seeps according to the analysis of the structure of microbial communities in sediments from the Gorevoy Utes oil seep areas using high-throughput sequencing [57]. In general, from 46 to $80 \%$ of microbial communities from the different sedimentary layers of oil seeps consisted of unique OTUs, and only 1 to $2 \%$ were shared [57, 58]. Sequences of Actinobacteria, Cyanobacteria, Proteobacteria, Thaumarchaeota, and Euryarchaeota dominated the communities in sediments $[57,58]$. The members of the phyla Chlorobi, Gemmatimonadetes, Nitrospirae, Planctomycetes, Armatimonadetes, Ca. Saccharibacteria Ca. Aminicenantes, Ca. Parcubacteria, and TM6 were minor in the 16S rRNA gene libraries [57]. 
The dominant taxa detected in the experimental enrichment cultures are more typical of microbial communities from deep methane hydrate-bearing sediments of the St. Petersburg methane seep (Lake Baikal) where Chloroflexi (38\%), Armatimonadetes (previously OP10/JS1 group) (19\%) and Caldiserica (OP5) (8\%) were the major components [59]. The investigated sediments, in particular the deep sample, included not only oil but also gas hydrates. Therefore, the influence of gas-saturated fluids may be responsible for the composition of microbial communities close to hydrate-bearing sediments and for the presence in sediments and enrichment cultures of the members of "rare taxa": Planctomycetes, Ca. Atribacteria (OP9), Ca. Armatimonadetes (OP10), Ca. division (OP11), Ca. Latescibacteria (WS3), Ca. division (AC1), and $\mathrm{Ca}$. Parcubacteria (OD1), which can be involved in hydrocarbon oxidation.

Microbial communities of enrichment cultures are mainly represented by uncultured microorganisms, whose closer homologues were identified in thermal habitats, sediments of mud volcanoes and environments contaminated with hydrocarbons, which are rather distant geographically from Lake Baikal. The detection of the same phylotypes of anaerobic bacteria phylogenetically similar to microorganisms from marine oil strata and high-temperature sediments in cold sediments of distant geographical locations is owing to their distribution by ocean currents [60]. Ocean currents play a key role in the passive spread of spores of thermophiles to distant locations from their origins. The transfer of cells from underground habitats to the overlying ocean also contributes to the marine microbial biodiversity, including representatives of the "rare biosphere" [61].

Lake Baikal located in the central part of the Baikal Rift Zone is not connected with the World Ocean by ocean currents. The identification of sequences of microorganisms having the closest homologues from mud volcanoes, oil and gas basin of the Sea of Okhotsk and Canada, as well as from thermal vents of Yellowstone Park, in the sediments of Lake Baikal associated with the discharge of hydrocarbons may be due to the activity of hydrothermal vents located at a depth of $5-6 \mathrm{~km}$, the generation of which was the most intense at the beginning of the Neogene [62]. In the same period, a modern system of mid-ocean ridges was formed in the World Ocean at the boundary between the Miocene and Pliocene. The entry of thermophiles from terrestrial hot springs located in the area of the Baikal rift may be another probable source of their occurrence in surface sediments. Thanks to the complex system of gradient and convection currents that determine the general circulation of water masses covering all three basins of Lake Baikal [63], thermophilic prokaryotes from terrestrial thermal vents could be brought in and buried in the surface sediments. All these hypotheses require study and will be the subject of further research.

\section{Declarations}

\section{Funding}

This work was supported by State Task number 0279-2021-0006 (121032300223-1).

\section{Acknowledgements}


Experimental cultivation, determination of the chemical composition of pore water in sediments and of polycyclic aromatic hydrocarbons and $n$-alkanes in model experiments were carried out using the equipment of the Freshwater aquarium complex and Collective Instrumental Center Ultramicroanalysis at Limnological Institute SB RAS; the Sanger reaction was performed by the SB RAS Genomics Core Facility (ICBFM SB RAS, Novosibirsk, Russia).

\section{Declarations}

The authors declare no conflict of interest.

\section{Authors' Contributions}

Pavlova O.N. performed data analysis and wrote the manuscript; Izosimova O.N. and Gorshkov A.G. determined PAHs and $n$-alkanes in model experiments; Chernitsyna S.M. analysed molecular biological data, Ivanov V.G. measured methane in bottom sediments and experimental samples, Pogodaeva T.V. conducted a chemical analysis of the composition of pore waters from sediments and storage cultures, Khabuev A.V. sampled sediments and described lithological core, Zemskaya T.I. coordinated the project and revised the manuscript.

\section{Data Availability}

Sequences used for phylogeny construction were deposited in the NCBI Nucleotide database under accession numbers: MW595796-MW595818, MW599318-MW599325, MW599327, MW599328, MW617235-MW617240, MW617242-MW617261, MW624372-MW624377, and MW633226MW633230.

\section{References}

1. Augustinovic Z, Birketveit O, Clements K, Freeman M, Gopi S, Ishoey T, Jackson G., Kubala G, Larsen J, Marcotte B, Scheie J, Skovhus T, Sunde E (2012) Microbes - oilfield enemies or allies? Oilfield Review 24:4-17.

2. Roling WFM, Head IM, Larter SR (2003) The microbiology of hydrocarbon degradation in subsurface petroleum reservoirs: perspectives and prospects. Res Microbiol 154:321-328.

www.elsevier.com/locate/resmic

3. Head IM, Larter SR, Gray ND, Sherry A, Adams JJ, Aitken CM, Jones DM, Rowan AK, Huang H, Roling WFM (2010) Hydrocarbon Degradation in Petroleum Reservoirs. In: Timmis K.N. (eds) Handbook of Hydrocarbon and Lipid Microbiology. Springer, Berlin, Heidelber, pp 3098-3110. https://doi.org/10.1007/978-3-540-77587-4_232

4. Gieg LM, Davidova IA, Duncan KE, Suflita JM (2010) Methanogenesis, sulfate reduction and crude oil biodegradation in hot Alaskan oilfields. Environ Microbiol 12:3074-3086. https://doi.org/10.1111/j.1462-2920.2010.02282.x 
5. Bian XY., Mbadinga SM, Liu YF, Yang SZ, Liu JF, Ye RQ, Gu JD, Mu BZ (2015) Insights into the anaerobic biodegradation pathway of $n$-alkanes in oil reservoirs by detection of signature metabolites. Sci Rep 5:9801. https://doi.org/10.1038/srep09801

6. Stagars MH., Ruff SE, Amann R, Knittel K (2016) High diversity of anaerobic alkane-degrading microbial communities in marine seep sediments based on (1-methylalkyl)succinate synthase genes. Front Microbiol 6:1511. https://doi.org/10.3389/fmicb.2015.01511

7. Cheng L, Shi SB, Yang L, Zhang YH, Dolfing J, Sun YG, Liu LY, Li Q, Tu B, Dai LR, Shi Q, Zhang H (2019) Preferential degradation of long-chain alkyl substituted hydrocarbons in heavy oil under methanogenic conditions. Org Geochem 138:103927 https://doi.org/10.1016/j.orggeochem.2019.103927

8. Pannekens M, Kroll L, Muller H, Mbow FT, Meckenstock RU (2019) Oil reservoirs, an exceptional habitat for microorganisms. New Biotechnol 49:1-9.https://doi.org/10.1016/j.nbt.2018.11.006

9. Ji JH, Liu YF, Zhou L, Mbadinga SM, Pan P, Chen J, Liu JF, Yang SZ, Sand W, Gu JD, Mu BZ (2019) Methanogenic degradation of long n-alkanes requires fumarate-dependent activation. Appl Environ Microbiol 85:e00985-19. https://doi.org/10.1128/aem.00985-19

10. Laczi K, Kis AE, Szilagyi A, Bounedjoum N, Bodor A, Vincze GE, Kovacs T, Rakhely G, Perei K (2020) New frontiers of anaerobic hydrocarbon biodegradation in the multi-omics era. Front Microbiol 11:590049. https://doi.org/10.3389/fmicb.2020.590049

11. Sierra-Garcia IN, Dellagnezze BM, Santos VP, Chaves MR, Capilla R, Neto EVS, Gray N, Oliveira VM (2017) Microbial diversity in degraded and non-degraded petroleum samples and comparison across oil reservoirs at local and global scales. Extremophiles 21:211-229. https://doi.org/10.1007/s00792016-0897-8

12. Dong XY, Greening C., Rattray JE, Chakraborty A, Chuvochina M, Mayumi D, Dolfing J, Li C, Brooks JM, Bernard BB, Groves RA, Lewis IA, Hubert CRJ (2019) Metabolic potential of uncultured bacteria and archaea associated with petroleum seepage in deep-sea sediments. Nat Commun 10:1816. https://doi.org/10.1101/400804

13. Mclntosh P, Schulthess CP, Kuzovkina YA, Guillard K (2017) Bioremediation and phytoremediation of total petroleum hydrocarbons (TPH) under various conditions. Int J Phytoremediation 19:755-764. https://doi.org/10.1080/15226514.2017.1284753

14. Zhang K, Hu Z, Zeng FF, Yang XY, Wang JJ, Jing R, Zhang HN, Li YT, Zhang Z (2019) Biodegradation of petroleum hydrocarbons and changes in microbial community structure in sediment under nitrate-, ferric-, sulfate-reducing and methanogenic conditions. J Environ Manage 249:109425. https://doi.org/10.1016/j.jenvman.2019.109425

15. Simoneit BRT, Aboul-Kassim TAT, Tiercelin JJ (2000) Hydrothermal petroleum from lacustrine sedimentary organic matter in the East African Rift. Appl Geochem 15:355-368. https://doi.org/10.1016/s0883-2927(99)00044-x

16. Zarate-del Valle PF, Rushdi Al, Simoneit BRT (2006) Hydrothermal petroleum of Lake Chapala, Citala Rift, western Mexico: Bitumen compositions from source sediments and application of hydrous 
pyrolysis. Appl Geochem 21:701-712. https://doi.org/10.1016/j.apgeochem.2006.01.002

17. Kontorovich AE, Kashirtsev VA, Moskvin VI, Burshtein LM, Zemskaya TI, Kostyreva EA, Kalmychkov GV, Khlystov OM (2007) Petroleum potential of Baikal Deposits. Russian Geol Geophys 48:10461053. https://doi.org/10.1016/j.rgg.2007.11.004

18. Khlystov OM, Gorshkov AG, Egorov AV, Zemskaya TI, Granin NG, Kalmychkov GV, Vorob'eva SS, Pavlova ON, Yakup MA, Makarov MM, Moskvin VI, Grachev MA (2007) Oil in the lake of world heritage. Dokl Earth Sci (Moscow) 415:682-685. https://doi.org/10.1134/S1028334X07050042

19. Khlystov OM, Zemskaya TI, Sitnikova TYa, Mekhanikova IV, Kaigorodova IA, Gorshkov AG, Timoshkin OA, Shubenkova OV, Chernitsyna SM, Lomakina AV, Likhoshvai AV, Sagalevich AM, Moskvin VI, Peresypkin VI, Belyaev NA, Slipenchuk MV, Tulokhonov AK, Grachev MA (2009) Bottom bituminous constructions and biota inhabiting them according to investigation of Lake Baikal with the Mir submersible. Dokl Earth Sci 429:1333-1336.

20. Sitnikova TYa, Zemskaya TI, Chernitsina SM, Likhoshway AV, Klimenkov IV, Naumova TV (2015) Structure of biocenoses formed on bitumen mounds in the abyssal zone of Lake Baikal. Russian J Ecol 3:292-298. https://doi.org/10.1134/S106741361503011X

21. Gorshkov A, Pavlova O, Khlystov O, Zemskaya T (2020) Fractioning of petroleum hydrocarbons from seeped oil as a factor of purity preservation of water in Lake Baikal (Russia). J Great Lakes Res 46:115-122. https://doi.org/10.1016/j.jglr.2019.10.010

22. Pavlova ON, Lomakina AV, Gorshkov AG, Suslova MYu, Likhoshvai AV, Zemskaya TI (2012) Microbial communities and their ability to oxidize n-alkanes in the area of release of gas- and oil-containing fluids in Mid-Baikal (Cape Gorevoi Utes). Biology Bulletin (Moscow) 39:458-463. https://doi.org/10.1134/s1062359012050123

23. Pavlova ON, Izosimova ON, Chernitsyna SM, Ivanov VG, Pogodaeva TV, Gorchkov AG (2020) Processes of anaerobic oxidation of oil in bottom sediments of Lake Baikal. Limnol Freshwater Biol 4:1006-1007. https://doi.org/10.31951/2658-3518-2020-A-4-1006

24. Widdel F, Pfennig N (1982) Studies on dissimilatory sulfate-reducing bacteria that decompose fatty acids II. Incomplete oxidation of propionate by Desulfobulbus propionicus gen. nov., sp. nov. Arch Microbiol 131:360-365. https://doi.org/10.1007/bf00406470

25. Netrusov A (2005) Microbiological Practicum. Student handbook, Academia Publ House, Moscow, 612 p. (in Russian).

26. Mizandrontsev IB, Kozlov VV, Ivanov VG, Kucher KM, Korneva ES, Granin NG (2020) Vertical distribution of methane in Baikal water. Water Res (Moscow) 47:122-129. ttps://doi.org/10.1134/s0097807820010108

27. Pogodaeva TV, Zemskaya TI, Golobokova LP, Khlystov OM, Minami H, Sakagami H (2007) Chemical composition of pore waters of bottom sediments in different Baikal basins. Russian Geol Geophys 48:886-900. https://doi.org/10.1016/j.rgg.2007.02.012

28. Sambrook J, Fritsch EF, Maniatis T (1989) Molecular Cloning. A Laboratory Manual. New York, Cold Spring Harbor, $545 \mathrm{p}$. 
29. Lane DJ (1991) 16S/23S rRNA sequencing. In: Stackebrandt E., Goodfellow M. (eds). Nucleic acid techniques in bacterial systematics. New York, John Wiley \& Sons, pp 115-175.

30. Hallam SJ, Girguis PR, Preston CM, Richardson PM, DeLong EF (2003) Identification of methyl coenzyme $M$ reductase $A$ (mcrA) genes associated with methane-oxidizing archaea. Appl Environ Microbiol. 69:5483-5491. https://doi.org/10.1128/aem.69.9.5483-5491.2003

31. Kumar S, Stecher G, Li M, Knyaz C, Tamura K (2018) MEGA X: Molecular Evolutionary Genetics Analysis across computing platforms. Mol Biol Evol 35:1547-1549. https://doi.org/10.1093/molbev/msy096

32. Pogodaeva TV, Lopatina IN, Khlystov OM, Egorov AV, Zemskaya TI (2017) Background composition of pore waters in Lake Baikal bottom sediments. J Great Lake Res 43:1030-1043. https://doi.org/10.1016/j.jglr.2017.09.003

33. Rissanen AJ, Peura S, Mpamah PA, Taipale S, Tiirola M, Biasi C, Mäki A, Nykänen H (2019) Vertical stratification of bacteria and archaea in sediments of a small boreal humic lake. FEMS Microbiol Lett 366:fnz044. https://doi.org/10.1093/femsle/fnz044

34. Eme L, Spang A, Lombard J, Stairs CW, Ettema TJG (2017) Archaea and the origin of eukaryotes. Nat Rev Microbiol 15:711-723. https://doi.org/10.1038/nrmicro.2017.133

35. Mori K, Sunamura M, Yanagawa K, Ishibashi J-I, Miyoshi Y, lino T, Suzuki K-I, Urabe T (2008) First cultivation and ecological investigation of a bacterium affiliated with the Candidate Phylum OP5 from hot springs. Appl Environ Microbiol 74:6223-6229. https://doi.org/10.1128/aem.01351-08

36. Youssef NH, Farag IF, Rinke C, Hallam SJ, Woyke T, Elshahed MS (2015) In silico analysis of the metabolic potential and niche specialization of Candidate Phylum "Latescibacteria" (WS3). PLoS ONE 10:e0127499. https://doi.org/10.1371/journal.pone.0127499

37. Kragelund C, Levantesi C, Borger A, Thelen K, Eikelboom D, Tandoi V, Kong Y, Van Der Waarde J, Krooneman J, Rossetti S, Thomsen TR, Nielsen PH (2007) Identity, abundance and ecophysiology of filamentous Chloroflexi species present in activated sludge treatment plants. FEMS Microbiol Ecol 59:671-682. https://doi.org/10.1111/j.1574-6941.2006.00251.x

38. Kadnikov VV, Mardanov AV, Beletsky AV, Karnachuk OV, Ravin NV (2019) Genome of the candidate phylum Aminicenantes bacterium from a deep subsurface thermal aquifer revealed its fermentative saccharolytic lifestyle. Extremophiles 23:189-200. https://doi.org/10.1007/s00792-018-01073-5

39. Hu P, Tom L, Singh A, Thomas BC, Baker BJ, Piceno YM, Andersen GL, Banfield JF (2016) Genomeresolved metagenomic analysis reveals roles for candidate phyla and other microbial community members in biogeochemical transformations in oil reservoirs. MBio 7:e01669-01615. https://doi.org/10.1128/mbio.01669-15

40. Dombrowski N, Seitz KW, Teske AP, Baker BJ (2017) Genomic insights into potential interdependencies in microbial hydrocarbon and nutrient cycling in hydrothermal sediments. Microbiome 5:106. https://doi.org/10.1186/s40168-017-0322-2

41. Zhang C, Meckenstock RU, Weng S, Wei G, Hubert CRJ, Wang J-H, Dong X (2020) Marine sediments harbor diverse archaea and bacteria with potentials for anaerobic hydrocarbon degradation via 
fumarate addition. Posted Content published. https://doi.org/10.21203/rs.3.rs-71489/v1

42. Miettinen $H$, Bomberg $M$, Nyyssönen $M$, Reunamo A, Jørgensen KS, Vikman $M$ (2019) Oil degradation potential of microbial communities in water and sediment of Baltic Sea coastal area. PLoS One 14:e0218834. https://doi.org/10.1371/journal.pone.0218834

43. Zemskaya TI, Bukin SV, Lomakina AV, Pavlova ON (2021) Microorganisms in bottom sediments of Lake Baikal, the world's deepest and oldest lake. Microbiology (Moscow) 3:in press.

44. Namsaraev BB, Zemskaya TI (2000) Microbiological processes of the carbon cycle in bottom sediments of Lake Baikal. Geo, Novosibirsk, 160 p. (In Russian).

45. Pavlova ON, Bukin SV, Lomakina AV, Kalmychkov GV, Ivanov VG, Morozov IV, Pogodaeva TV, Pimenov NV, Zemskaya TI (2014) Production of gaseous hydrocarbons by microbial communities of Lake Baikal bottom sediments. Microbiology (Moscow) 83:798-804. https://doi.org/10.1134/s0026261714060137

46. Bukin SV, Pavlova ON, Kalmychkov GV, Ivanov VG, Pogodaeva TV, Galachyants YuP, Bukin YuS, Khabuev AV, Zemskaya TI (2018) Substrate specificity of methanogenic communities from Lake Baikal bottom sediments associated with hydrocarbon gas discharge. Microbiology (Moscow) 87:549-558. https://doi.org/10.1134/s0026261718040045

47. Rabus R, Boll M, Heider J, Meckenstock RU, Buckel W, Einsle O, Ermler U, Golding BT, Gunsalus RP, Kroneck PMH, Krüger M, Lueders T, Martins BM, Musat F, Richnow HH, Schink B, Seifert J, Szaleniec M, Treude T, Ullmann GM, Vogt C, von Bergen M, Wilkes H (2016) Anaerobic microbial degradation of hydrocarbons: from enzymatic reactions to the environment. J Mol Microbiol Biotechnol 26:5-28. https://doi.org/10.1159/000443997

48. Tan BF, Semple K, Foght J (2015) Anaerobic alkane biodegradation by cultures enriched from oil sands tailings ponds involves multiple species capable of fumarate addition. FEMS Microbiol Ecol 91:fiv042. https://doi.org/10.1093/femsec/fiv042

49. Boopathy R (2004) Anaerobic biodegradation of no. 2 diesel fuel in soil: a soil column study. Bioresour Technol 94:143-151.https://doi.org/10.1016/j.biortech.2003.12.006

50. Falkner KK, Measures Cl, Herbelin SE, Edmond JM, Weiss RF (1991) The major and minor element geochemistry of Lake Baikal. Limnol Oceanogr 36:413-423. https://doi.org/10.4319/lo.1991.36.3.0413

51. Ma TT, Liu LY, Rui JP, Yuan Q, Feng DS, Zhou Z, Dai LR, Zeng WQ, Zhang H, Cheng L (2017) Coexistence and competition of sulfate-reducing and methanogenic populations in an anaerobic hexadecane-degrading culture. Biotechnol Biofuels 10:207. https://doi.org/10.1186/s13068-0170895-9

52. Pavlova ON, Izosimova ON, Gorshkov AG, Novikova AS, Bukin SV, Ivanov VG, Khlystov OM, Zemskaya TI (2020) Current state of deep oil seepage near cape Gorevoi Utes (Central Baikal). Russian Geol Geophys 61:1007-1014. https://doi.org/10.15372/rgg2019180

53. Pimenov NV, Zakharova EE, Bryukhanov AL, Korneeva VA, Kuznetsov BB, Tourova TP, Pogodaeva TV, Kalmychkov GV, Zemskaya TI (2014) Activity and structure of the sulfate-reducing bacterial 
community in the sediments of the southern part of Lake Baikal. Microbiology (Moscow) 83:47-55. https://doi.org/10.1134/s0026261714020167

54. Gray ND, Sherry A, Hubert C, Dolfing J, Head IM (2010) Methanogenic degradation of petroleum hydrocarbons in subsurface environments: remediation, heavy oil formation, and energy recovery. In: Laskin A.I., Sariaslani S., Gadd G.M. (eds). Adv Appl Microbiol Academic Press, pp 137-161. https://doi.org/10.1016/s0065-2164(10)72005-0

55. Wentzel A, Lewin A, Cervantes FJ, Valla S, Kotlar HK (2013) Deep subsurface oil reservoirs as polyextreme habitats for microbial life. A current review. In: Seckbach J, Oren A, Stan-Lotter H (eds). Polyextremophiles. Cellular Origin, Life in Extreme Habitats and Astrobiology. Springer, Dordrecht, pp 439-466. https://doi.org/10.1007/978-94-007-6488-0_19

56. Kleinsteuber S, Schleinitzm KM, Vogt C (2012) Key players and team play: anaerobic microbial communities in hydrocarbon-contaminated aquifers. Appl Microbiol Biotechnol 94:851-873. https://doi.org/10.1007/s00253-012-4025-0

57. Zemskaya TI, Lomakina AV, Mamaeva EV, Zakharenko AS, Pogodaeva TV, Petrova DP, Galachyants YuP (2015) Bacterial communities in sediments of Lake Baikal from areas with oil and gas discharge. Aquat Microbial Ecol 76:95-109. https://doi.org/10.3354/ame01773

58. Lomakina AV, Pogodaeva TV, Morozov IV, Zemskaya TI (2014) Microbial communities of the discharge zone of oil and gas-bearing fluids in low-mineral Lake Baikal. Microbiology 83:278-287. https://doi.org/10.1134/s0026261714030126

59. Kadnikov VV, Mardanov A, Beletsky AV, Shubenkova OV, Pogodaeva TN, Zemskaya TI, Ravin NV, Skryabin KG (2012) Microbial community structure in methane hydrate-bearing sediments of freshwater Lake Baikal. FEMS Microbiol Ecol 79:348-358. https://doi.org/10.1111/j.15746941.2011.01221.x

60. Chakraborty A, Ruff SE, Dong X, Ellefson ED, Li C, Brooks JM, McBee J, Bernard BB, Hubert CRJ (2020) Hydrocarbon seepage in the deep seabed links subsurface and seafloor biospheres. Proc Natl Acad Sci USA 117:11029-11037https://doi.org/10.1073/pnas.2002289117

61. Müller AL, de Rezende JR, Hubert CRJ, Kjeldsen KU, Lagkouvardos I, Berry D, Jorgensen BoB, Loy A (2014) Endospores of thermophilic bacteria as tracers of microbial dispersal by ocean currents. ISME J 8:1153-1165. https://doi.org/10.1038/ismej.2013.225

62. Lomonosov IS (1974) Geochemistry and formation of modern hydrotherms in the Baikal Rift Zone. Nauka, Novosibirsk, 168 p. (In Russian).

63. Verbolov VI (1996) Currents and water exchange in Lake Baikal. Water Res 23:381-391.

\section{Figures}




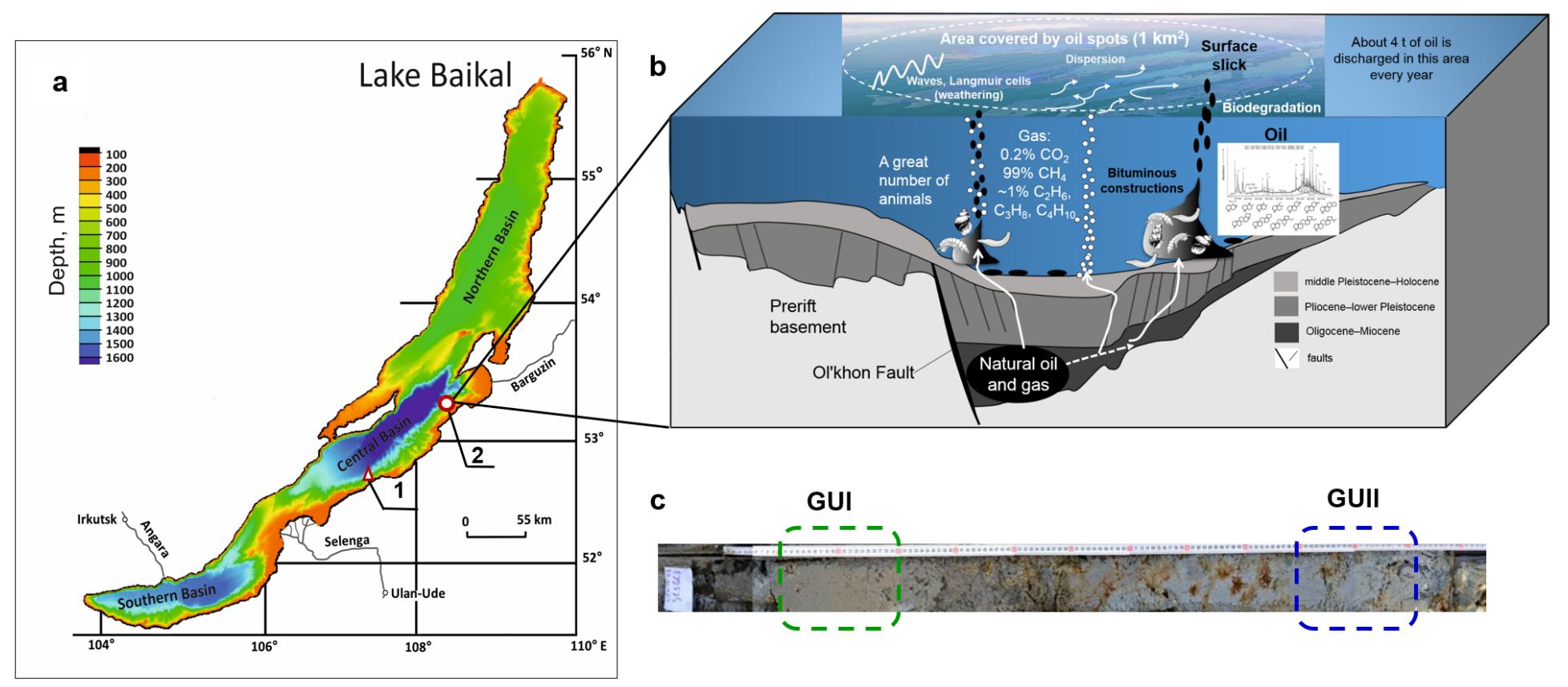

Figure 1

(a) Schematic map of Lake Baikal. 1 - B. the Zelenovskaya River; 2 - Gorevoy Utes oil-methane seep. (b) Schematic illustration of the processes occurring at the site of natural oil seepage located near Gorevoy Utes Cape [21]. The schematic section and modern faults are shown according to [18]. (c) Symbols of integrated samples of bottom sediments collected for the experiment.
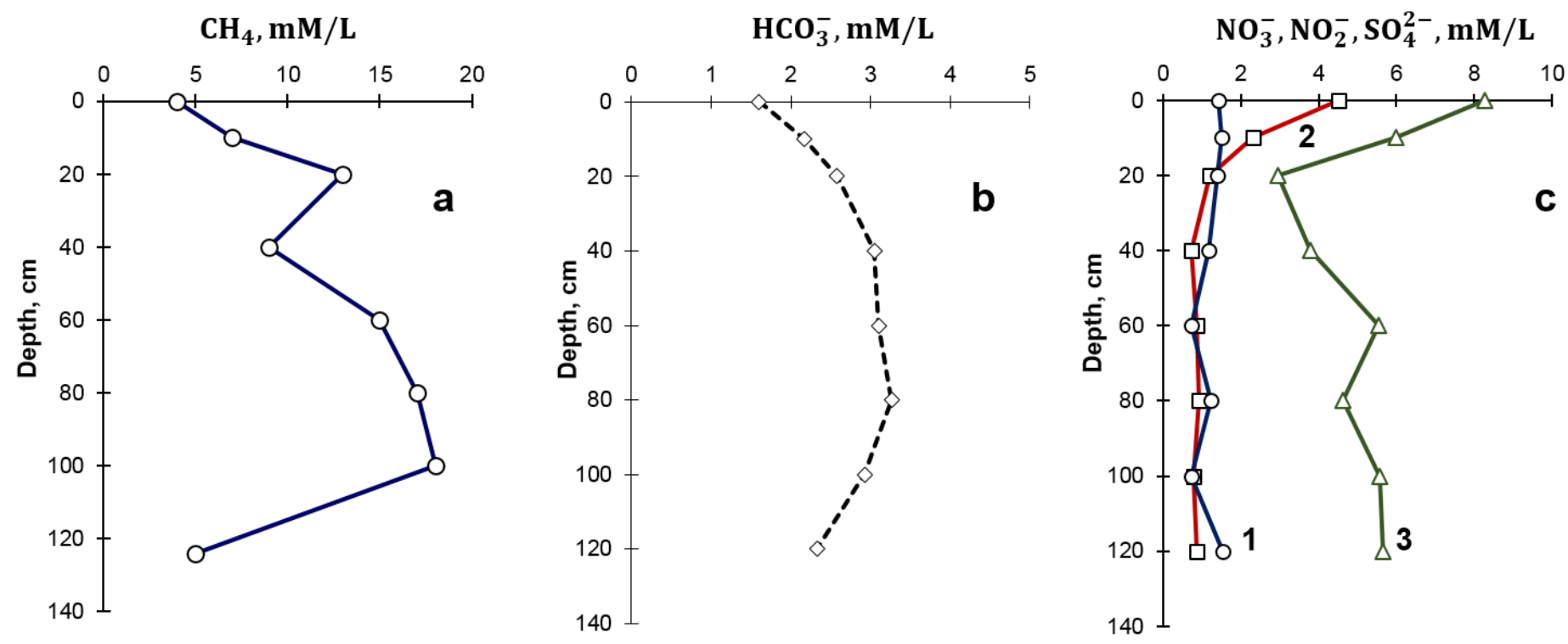

Figure 2

Concentration profile of the components in the chemical composition of pore waters from the St.5, GC.3 core: (a) methane, (b) bicarbonate ion, (c) nitrate ions (1), nitrite ions (2) and sulfate ions (3). 


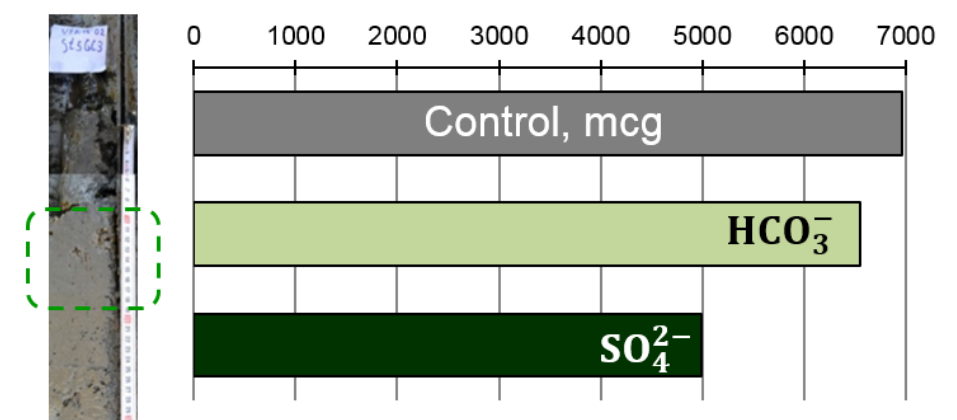

a

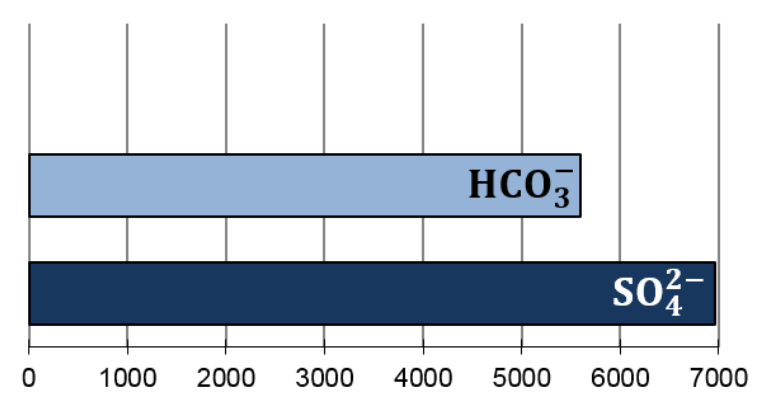

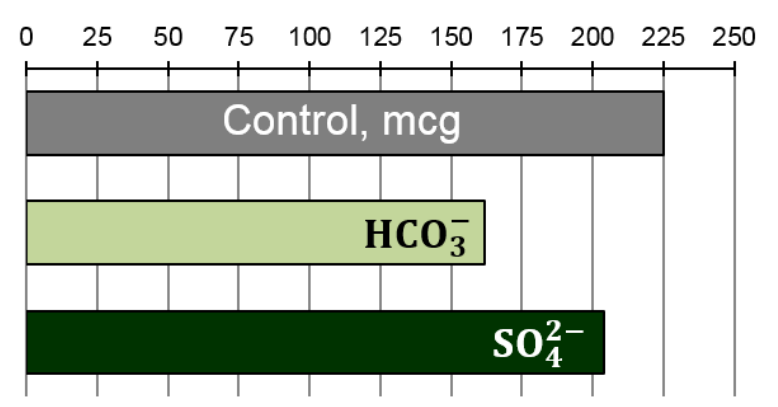

b

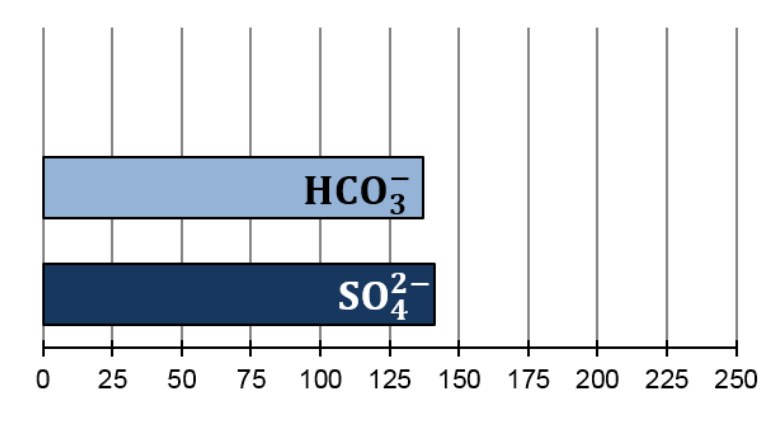

Figure 3

Loss of n-alkanes (a) and PAHs (b) in the cultures containing the surface and deep sediments enriched with bicarbonate and sulfate ions. 


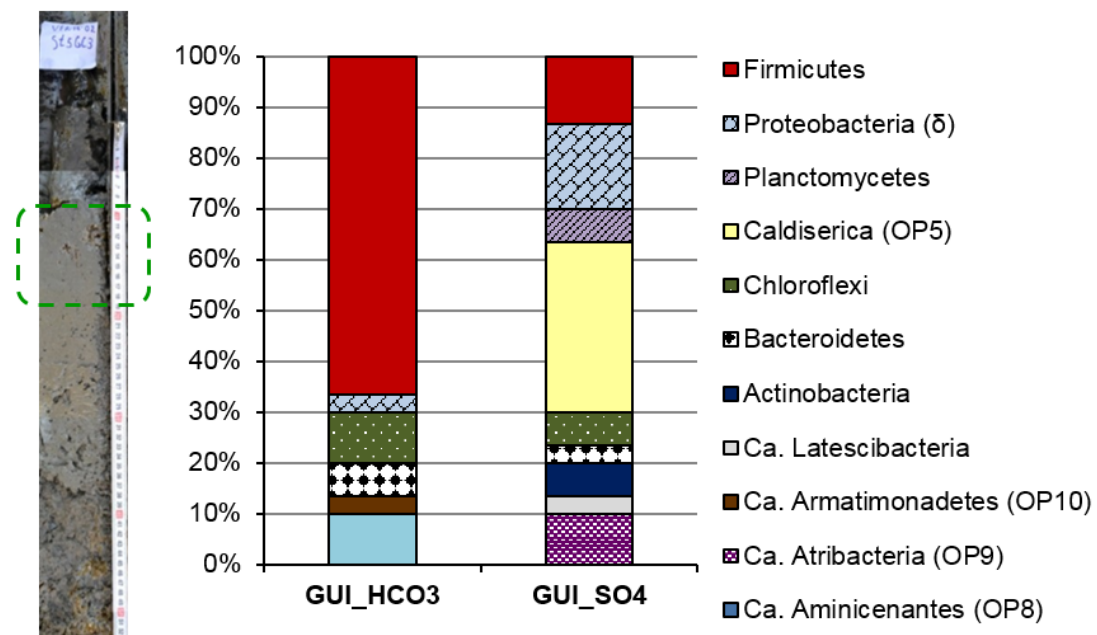

a

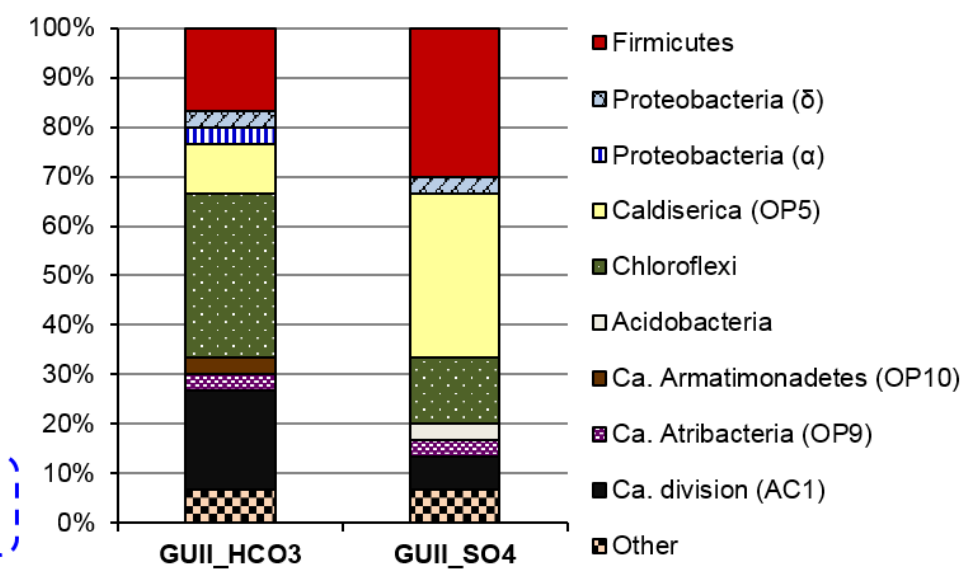

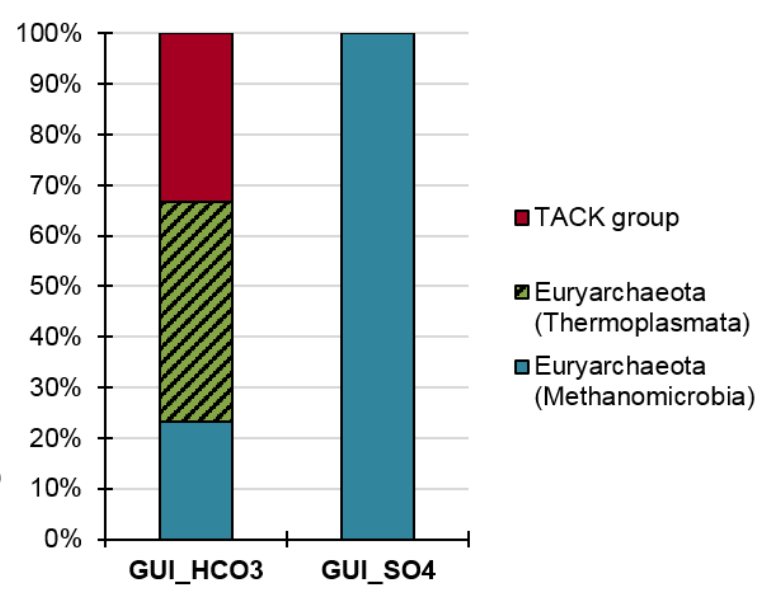

b

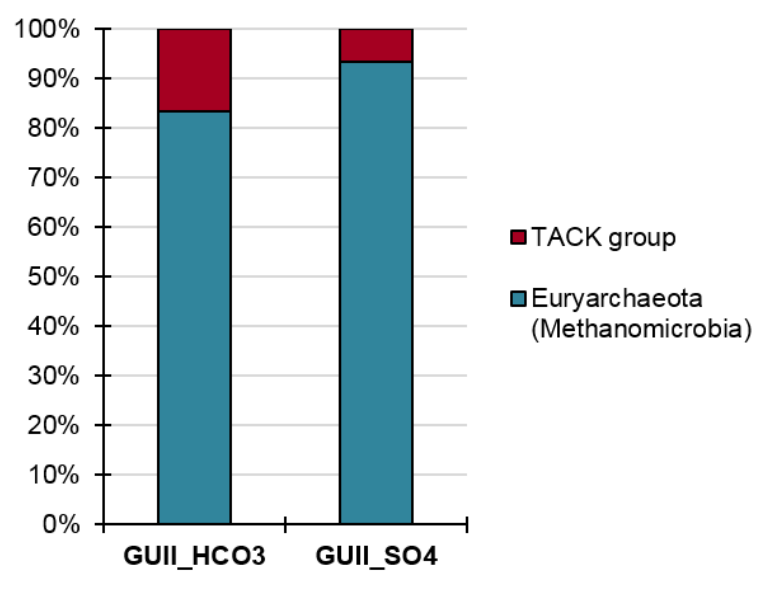

Figure 4

The composition of the clone libraries of the 16s r RNA genes of bacteria (a) and archaea (b) in the cultures containing the surface and deep sediments enriched with bicarbonate and sulfate ions. 


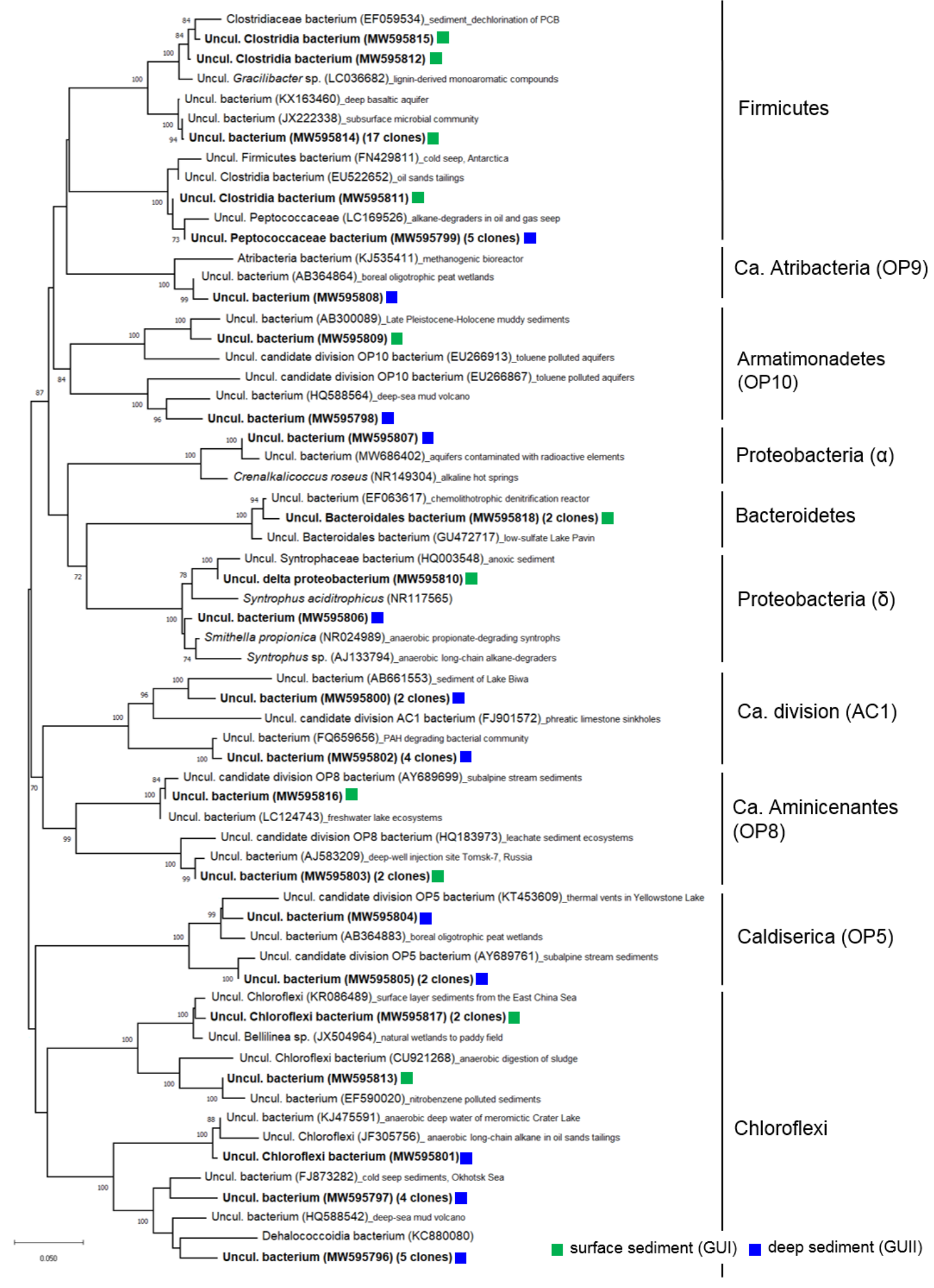

Figure 5

Phylogenetic tree based on the $16 \mathrm{~S} r$ RNA gene sequences indicating the position of bacteria from the cultures containing the surface and deep sediments enriched with bicarbonate ions. The sequences obtained are marked in bold in the phylogenetic tree. The scale bar shows the evolutionary distance corresponding to one nucleotide sequence per 100 nucleotides. The numbers indicate the reliability of branches determined using bootstrapping, an analysis of alternative trees. 


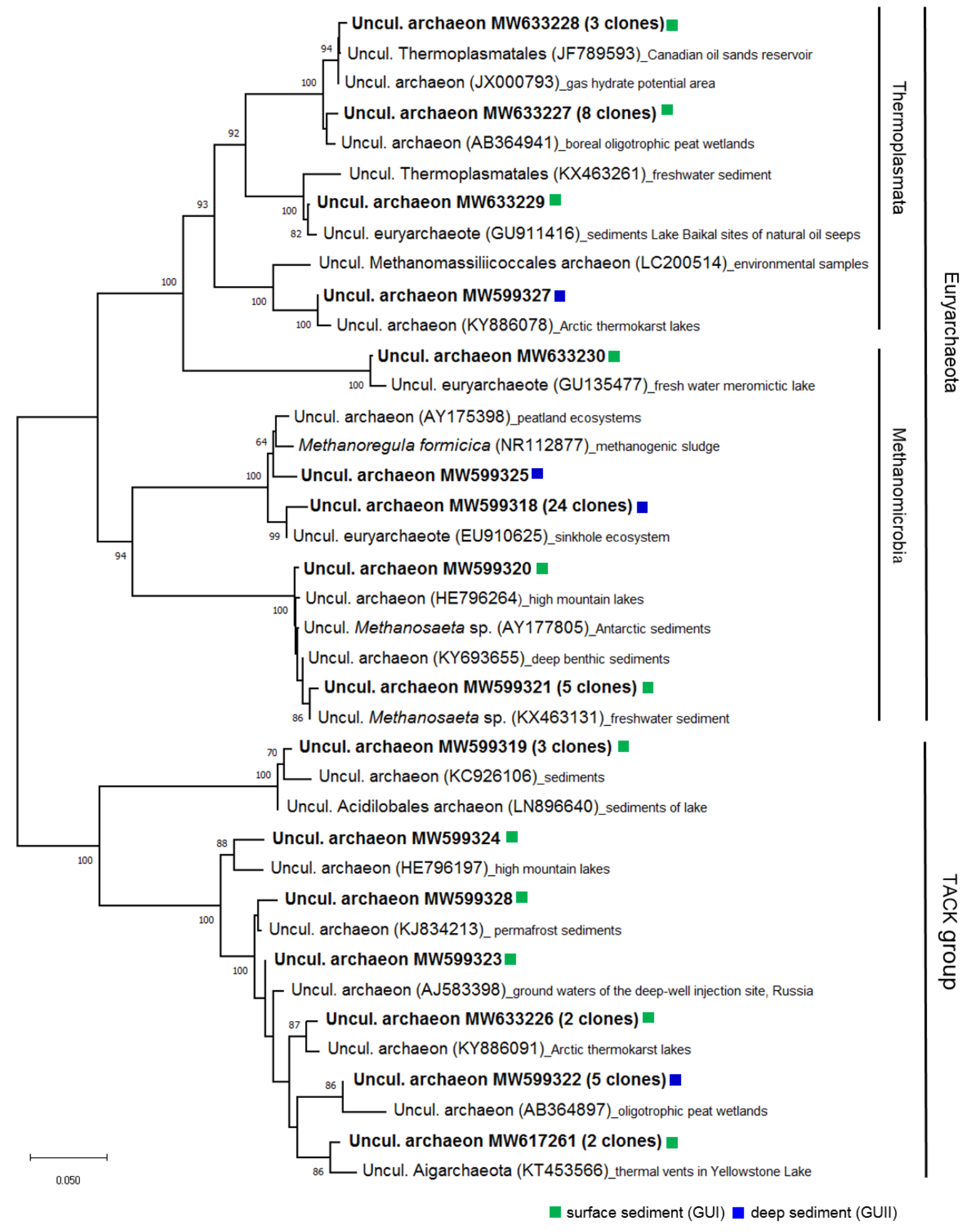

Figure 6

Phylogenetic tree based on the 16S r RNA gene sequences indicating the position of archaea from the cultures containing the surface and deep sediments enriched with bicarbonate ions. The sequences obtained are marked in bold in the phylogenetic tree. The scale bar shows the evolutionary distance corresponding to one nucleotide sequence per 100 nucleotides. The numbers indicate the reliability of branches determined using bootstrapping, an analysis of alternative trees. 


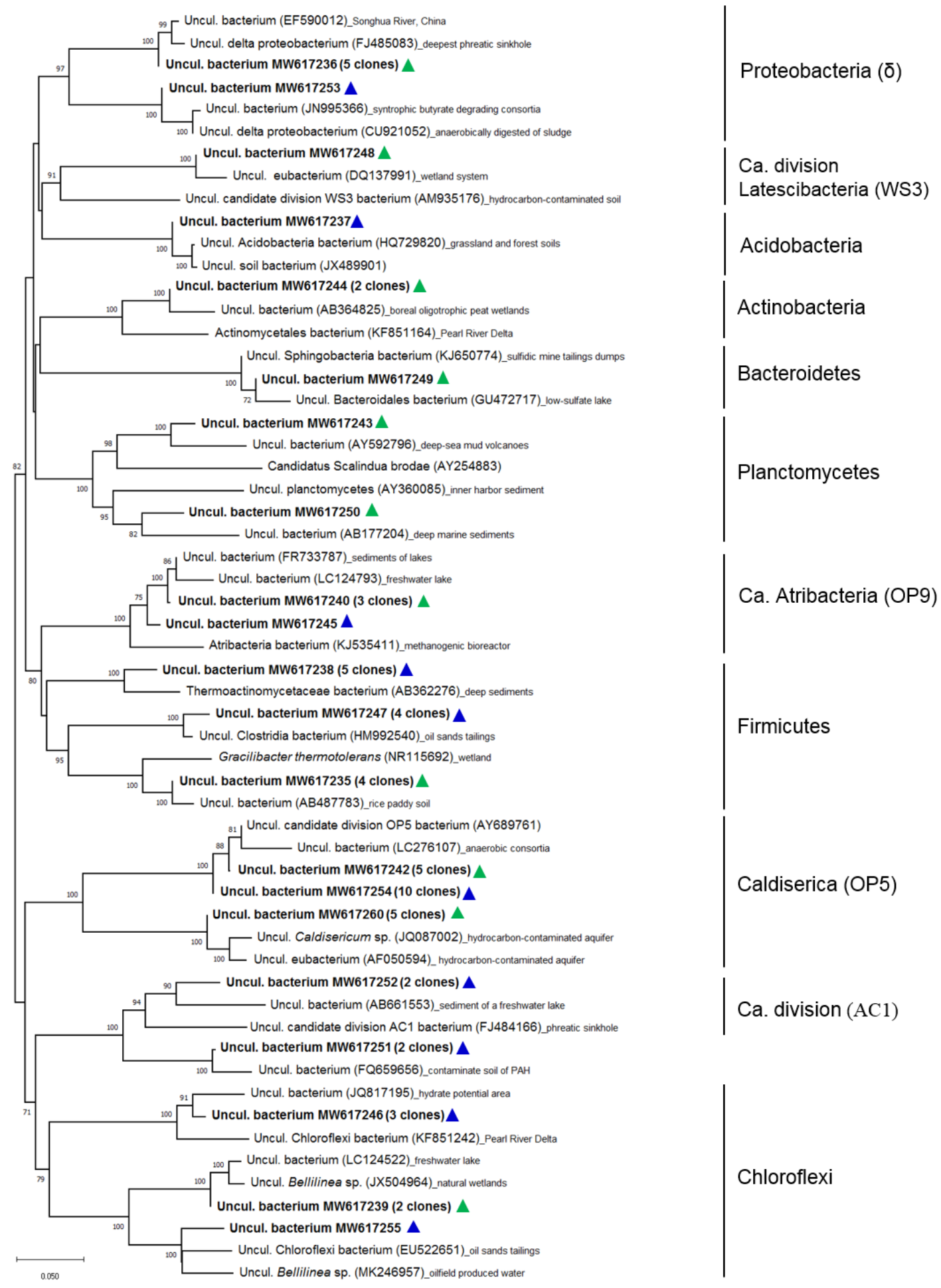

$\Delta$ surface sediment (GUI) $\boldsymbol{\Delta}$ deep sediment (GUII)

Figure 7

Phylogenetic tree based on the 16S r RNA gene sequences indicating the position of bacteria from the cultures containing the surface and deep sediments enriched with sulfate ions. The sequences obtained are marked in bold in the phylogenetic tree. The scale bar shows the evolutionary distance corresponding to one nucleotide sequence per 100 nucleotides. The numbers indicate the reliability of branches determined using bootstrapping, an analysis of alternative trees. 


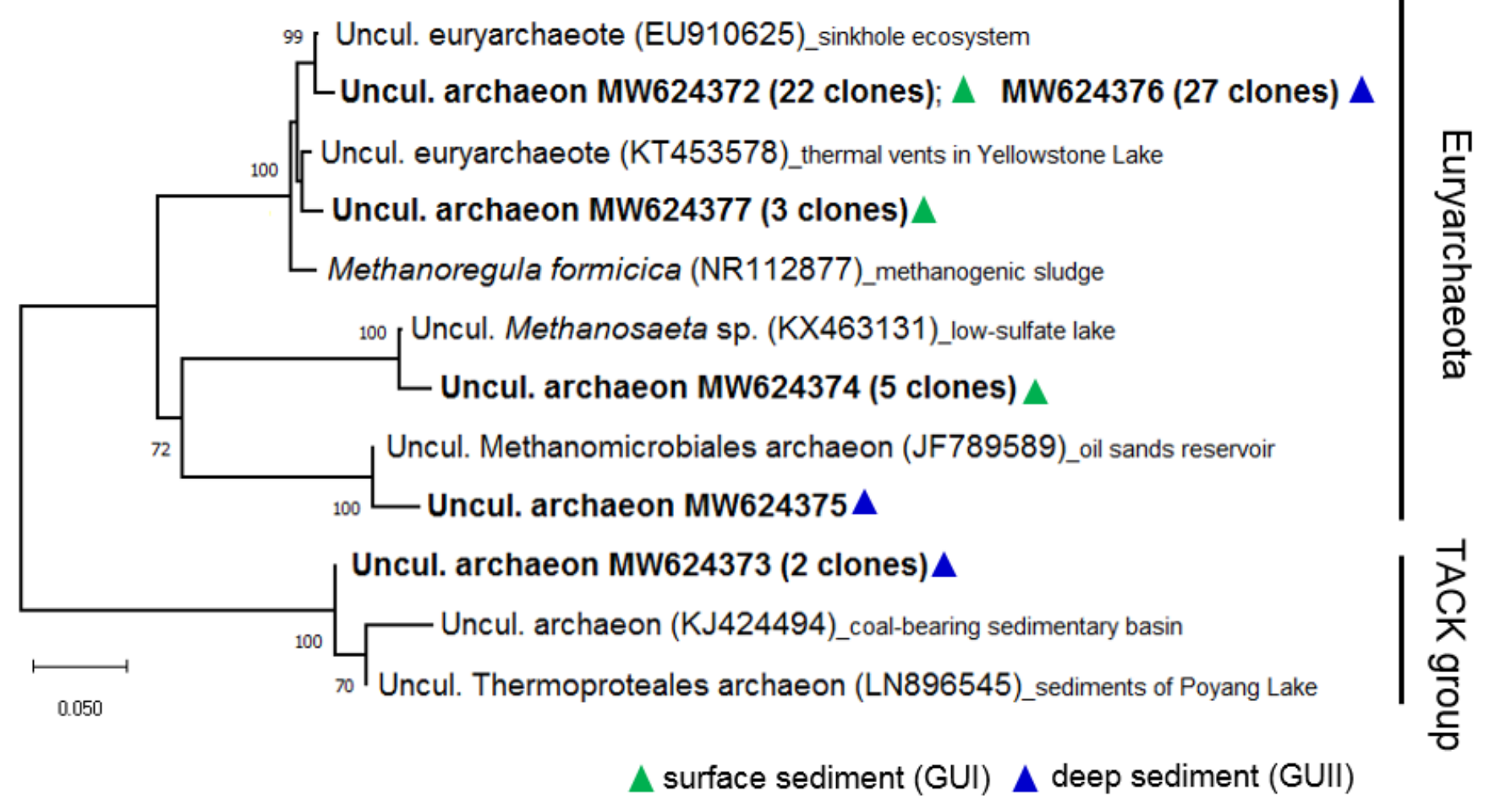

Figure 8

Phylogenetic tree based on the 16S r RNA gene sequences indicating the position of archaea from the cultures containing the surface and deep sediments enriched with sulfate ions. The sequences obtained are marked in bold in the phylogenetic tree. The scale bar shows the evolutionary distance corresponding to one nucleotide sequence per 100 nucleotides. The numbers indicate the reliability of branches determined using bootstrapping, an analysis of alternative trees.

\section{Supplementary Files}

This is a list of supplementary files associated with this preprint. Click to download.

- SupplTables14.docx 